
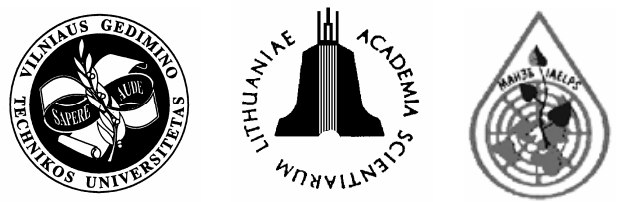

\title{
INFLUENCE OF STEVEDORING OPERATIONS OF LIQUID AND POWDERY FERTILIZERS AT KLAIPĖDA STATE SEAPORT ON THE AMBIENT AIR QUALITY
}

\author{
Pranas Baltrẻnas $^{1}$, Mindaugas Kvasauskas ${ }^{2}$, Klaus-Dieter Frőhner ${ }^{3}$ \\ ${ }^{1,2}$ Dept of Environmental Protection, Vilnius Gediminas Technical University, Sauletekio al. 11, LT-10223 Vilnius, \\ Lithuania.E-mail:aak@ap.vtu.lt \\ ${ }^{3}$ Hamburg-Harburg Technical University, Eißendorfer Str. 40, D-21073 Hamburg, Germany \\ Submitted 8 Mar 2006; accepted 25 Mar 2006
}

\begin{abstract}
Economic operations carried out at Klaipeda State Seaport negatively affect the quality of the ambient air. To assess the atmosphere pollution in northern Klaipeda caused by economic operations at the Port, investigation was carried out from June to November. This paper surveys the influence of stevedoring and transportation of liquid and powdery fertilizers on the ambient air. Measurements of ammonia and phosphorus acid concentrations in the air showed that the concentrations and distribution of ammonia concentrations were for the most part influenced by meteorological conditions the wind force and relative air humidity - as well as by transportation of liquid fertilizers. The largest excess of the maximum permissible concentration (MPC) of ammonia concentration was recorded in June: at daytime and in the evening it was higher 1,1 time, and at night - 2,2 times. In September, October and November ammonia concentrations in the ambient air did not exceed the MPC. Excess of phosphorus acid concentrations in the ambient air was detected in June $(1,2$ time at daytime) and July (at daytime and in the evening) in the closest proximity of the Liquid Fertilizer Transhipment Terminal.
\end{abstract}

Keywords: air pollution, ammonia concentration, phosphorus acid concentration, meteorological conditions.

\section{Introduction}

Klaipeda is a growing industrial city-port having more than 60 large enterprises [1]. The dominant industrial branches include energy, furniture manufacture, wood treatment and ship repair. The seacoast of the Curonian Lagoon and the Baltic Sea has concentrated the main industrial enterprises and plants of the city along with the state seaport, AB Baltija Shipbuilding Yard, two oil companies and other establishments. Air pollution problems are relevant to Klaipeda like to other major European cities.

Economic activities carried out at the Port have major impact on the pollution of the ambient air in Klaipeda city [2]. AB Klaipèdos Jūrų Krovinių Kompanija (Klaipeda Stevedoring Company, KLASCO), based in a strategic part of the seaport, annually handles more than 8 million tons of cargos and is expanding its capacities. KLASCO holds 6 terminals: general cargo, bulk mineral fertilizers, liquid fertilizers, grain, and Ro-Ro.

With the aim to determine and assess pollution from the Port in the northern part of Klaipeda, the concentrations of ammonia, nitric and sulphuric dioxide, carbon monoxide, solid particles and phosphorus acid in the ambient air were measured [3, 4]. This paper surveys and analyses possible impact of economic activities at the Port on the ambient air - the distribution of ammonia and phosphorus acid in northern Klaipeda. These are the main emissions at the Port during the stevedoring operations of liquid and powdery fertilizers.

\section{Measuring methods}

Measurements of the air pollution in northern Klaipeda were carried out for seven months, i e from June to November. The measuring of emissions was carried out for one week per month. Attempts were made to maintain equal 3-week intervals between measurements. Seeking to evaluate the change of pollutants within the course of a day and have a more precise evaluation of their concentrations, depending on the intensity of pollution sources, the measuring was carried out at daytime, in the evening and at night.

Measuring points of the ambient air pollutants were allocated proportionally over the entire northern territory of Klaipedda. 16 measuring points were selected for investigation (Fig 1). Pollutant measuring points were arranged in two lines (areas). The areas were selected so as to reflect the influence of the city's and Port's infrastructure on the ambient air. The first line (area) of measuring points was arranged near Švyturio and Naujoji Uosto Streets (10-50 m from AB KLASCO). The second one was allocated in parallel to the first one (200-300 m from AB KLASCO) near S. Šimkaus, I. Kanto and Sportininku Streets. 


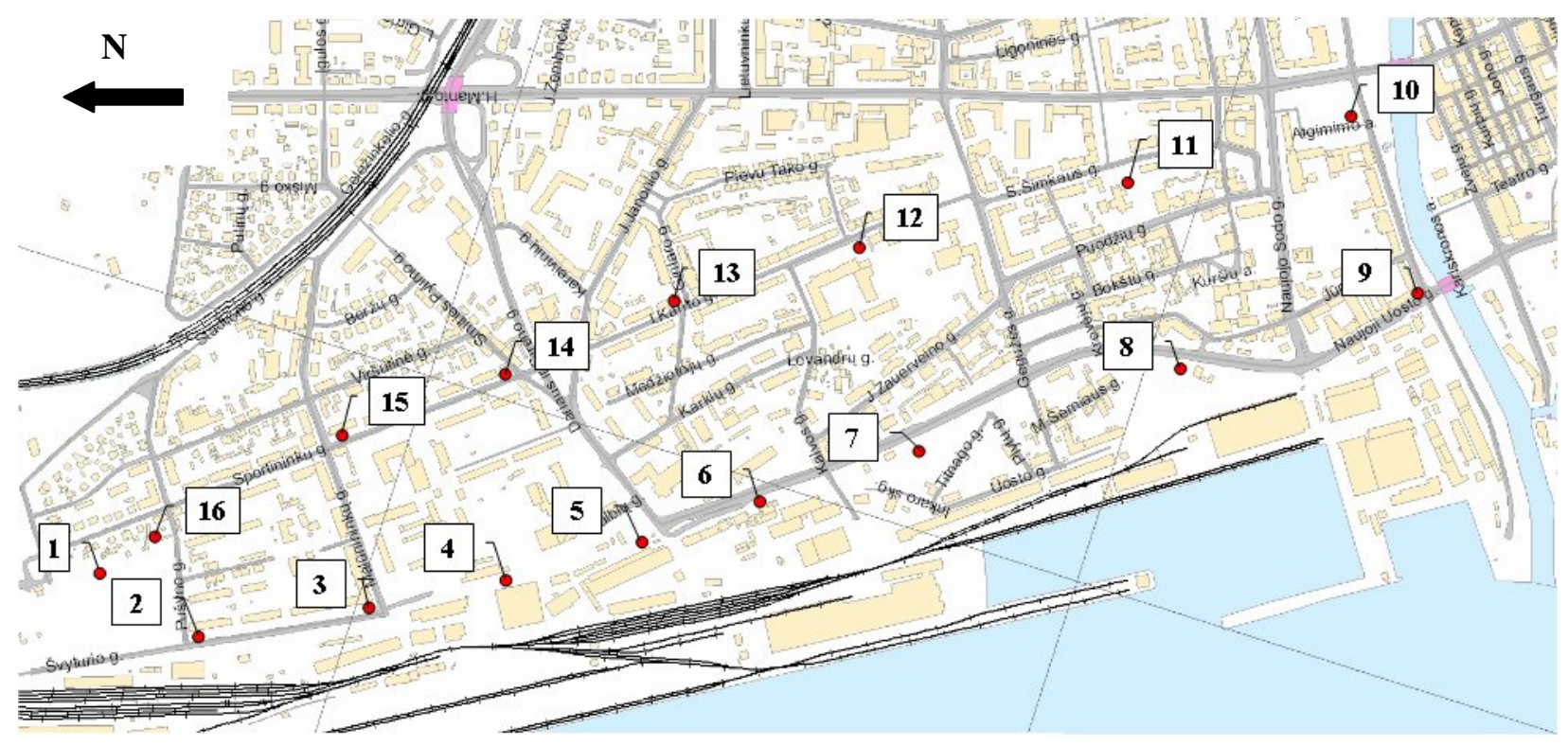

Fig 1. Layout of measuring points of ambient air pollutant concentrations

The measuring places of pollutant concentrations and the time of measuring in the course of a day were selected randomly $[5,6]$.

Ammonia concentration was recorded by a photometric method. Sampling was performed by bubbling devices into $0,1 \%$ sulphuric acid solution. The concentration of phosphorus acid was also determined by a photometric method. While sucking air with SKC MCS aspirator, phosphorus pentoxide was precipitated on AФA filters, and afterward its concentration was recalculated into phosphorus acid concentration.

During the ambient air sampling the following parameters of meteorological conditions were recorded: temperature, relative air humidity, the wind speed and direction.

\section{Research findings}

Pollutant concentrations at each measuring point are presented in diagrams and compared to the MPC [7], and possible causes of increase in pollutant concentrations are discussed. In addition, comparison of pollutant concentrations in areas I and II is made.

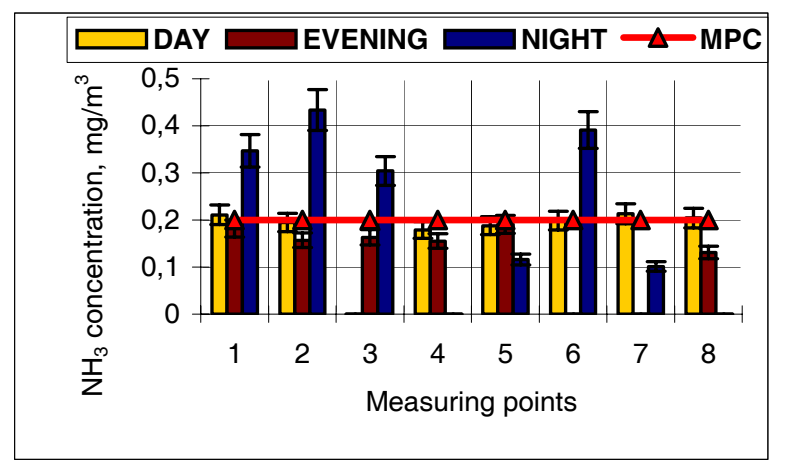

\subsection{Ammonia}

Ammonia concentration measured at daytime, in the evening and at night in June is presented in Fig 2.

An average concentration at daytime was $0,16 \mathrm{mg} / \mathrm{m}^{3}$, in the evening $-0,15 \mathrm{mg} / \mathrm{m}^{3}$, at night $0,17 \mathrm{mg} / \mathrm{m}^{3}$.

In area I the concentration of ammonia in the atmospheric air was higher at daytime and at night. At daytime the difference reached 1,20 time, at night - 1,58 time, in the meantime in area II the concentration in the evening was 1,36 time bigger than in area I.

The MPC was exceeded at daytime, in the evening and at night. An excess of the MPC at daytime was recorded at 4 measuring points, in the evening - at 1 measuring point and at night - at 6 points. The largest MPC excess was recorded during night measurements. The largest MPC excess (2,17 times) was recorded at measuring point 2. A larger excess was also fixed at measuring points 1, 3, 6 and 16. The MPC was exceeded 1,74, 1,52, 1,96 and 1,74 time, respectively.

Ammonia concentration measured in July is presented in Fig 3.

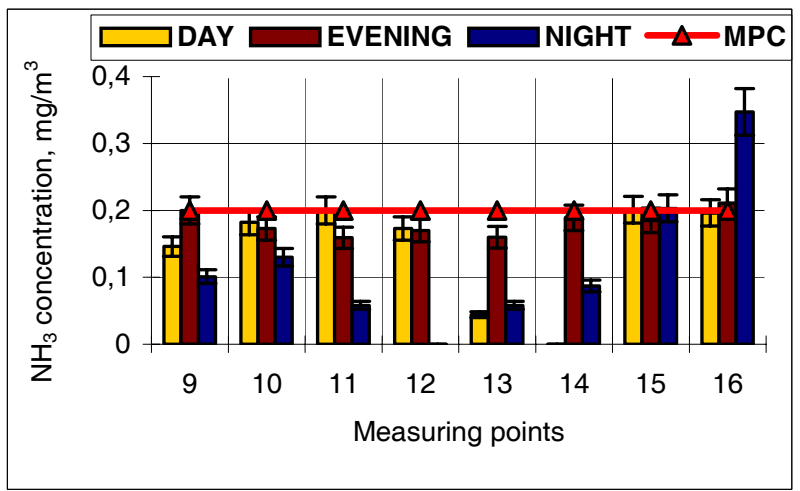

Fig 2. Ammonia concentration 10-50 m and 200-300 m from AB KLASCO territory in June 

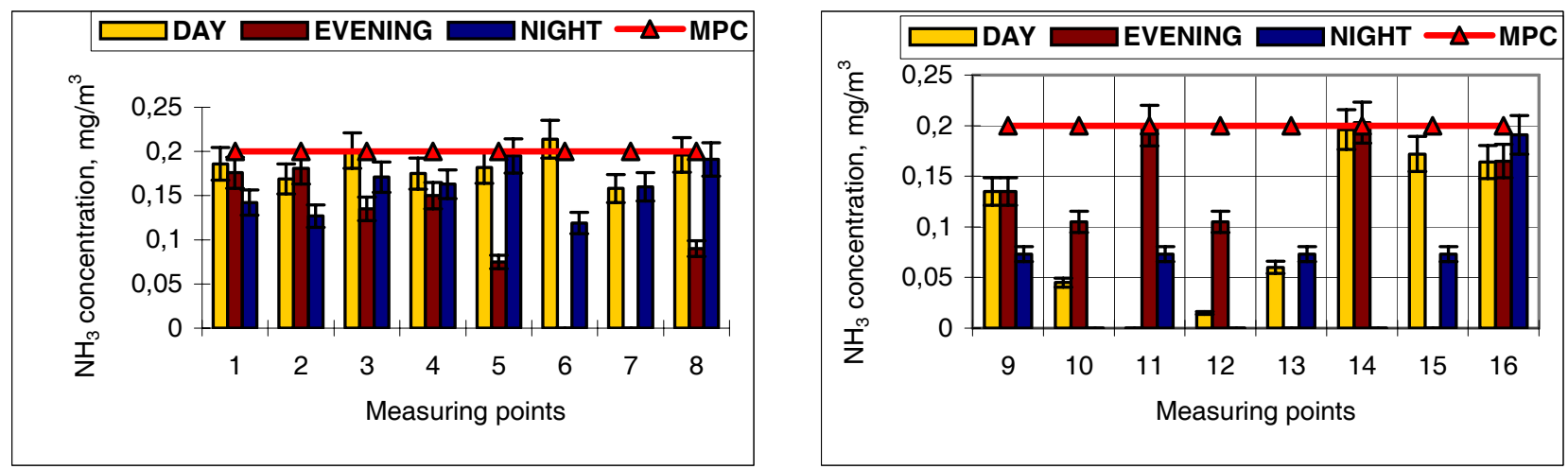

Fig 3. Ammonia concentration 10-50 m and 200-300 m from AB KLASCO territory in July
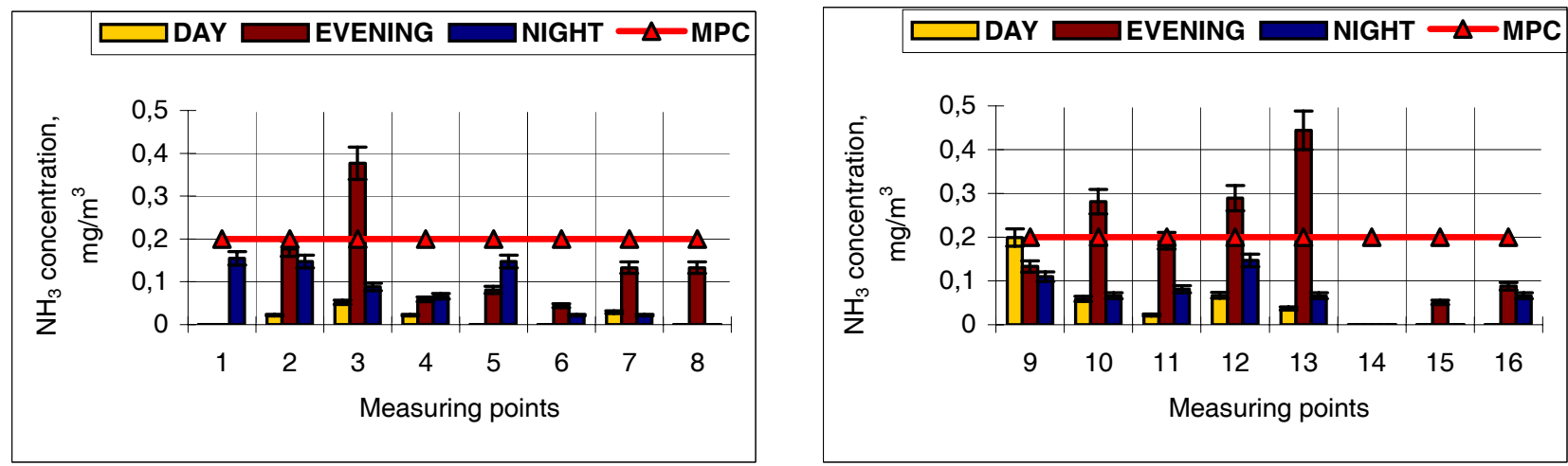

Fig 4. Ammonia concentration 10-50 m and 200-300 m from AB KLASCO territory in August
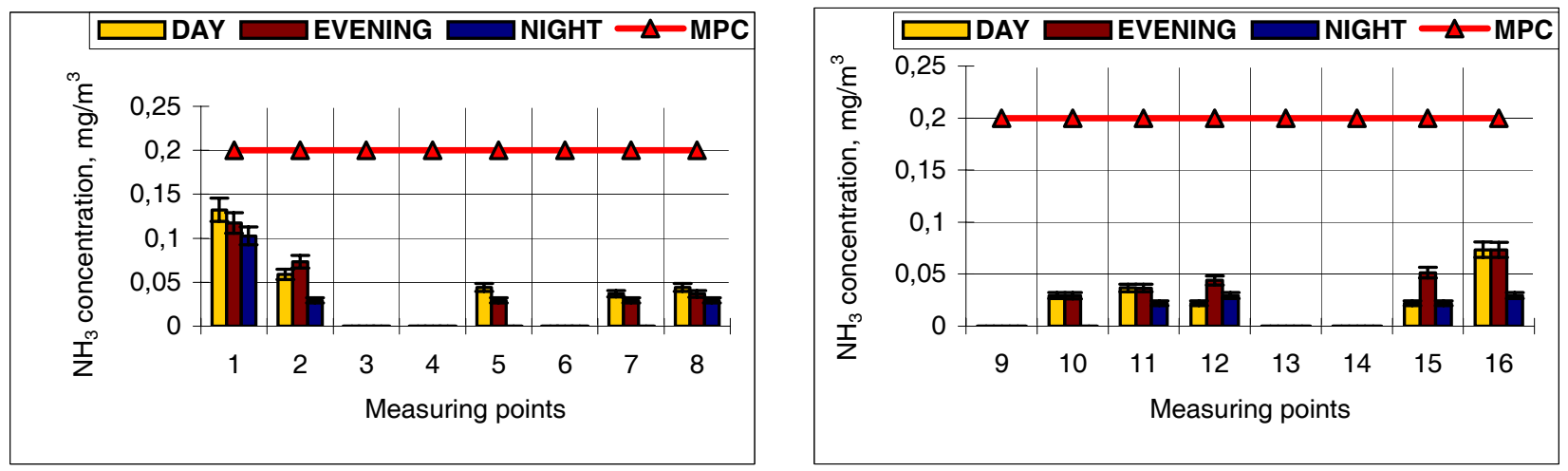

Fig 5. Ammonia concentration $10-50 \mathrm{~m}$ and $200-300 \mathrm{~m}$ from AB KLASCO territory in September

At daytime an average concentration reached $0,14 \mathrm{mg} / \mathrm{m}^{3}$, in the evening and at night it decreased to $0,11 \mathrm{mg} / \mathrm{m}^{3}$.

Comparison of areas I and II showed different concentrations of ammonia in the atmospheric air: in area I they were higher at daytime and at night. At daytime this difference approached 1,93 time, at night $-2,54$ times, whereas in the evening the concentration in area II was 1,06 time higher than in area I.

The MPC was exceeded at daytime at points 3 and 6 , and in the evening at measuring point $14(1,01,1,07$ and 1,02 time, respectively).

Fig 4 presents ammonia concentration measured in August.
Ammonia concentrations were not evenly distributed within a 24-hour day - at daytime and at night the concentrations were low and they did not exceed the MPC, however, in the evening, a significant increase in ammonia concentration was observed. Average concentrations at daytime and at night amounted to $0,03 \mathrm{mg} / \mathrm{m}^{3}$ and $0,07 \mathrm{mg} / \mathrm{m}^{3}$, respectively, and in the evening they increased up to $0,16 \mathrm{mg} / \mathrm{m}^{3}$.

Areas I and II had different ammonia concentrations in the atmospheric air: they were higher at daytime and at night in area I. The daytime difference was 1,36 time, the night difference was 1,38 time, and in the evening the concentration in area II was 1,52 time higher than in area I.

The MPC was exceeded at separate points during evening measurements. The majority of excesses was 
recorded at the measuring points of area II. The MPC was exceeded only during evening measurements. Excess was recorded at measuring points $3,10,12$ and 13 . The highest excess of the MPC was recorded at points 3 and 13 , i e 1,89 and 2,22 times, respectively.

Ammonia concentration measured in September is presented in Fig 5.

Average concentrations at daytime and at night were $0,031 \mathrm{mg} / \mathrm{m}^{3}$ and $0,032 \mathrm{mg} / \mathrm{m}^{3}$, respectively, and at night they decreased to $0,017 \mathrm{mg} / \mathrm{m}^{3}$.

In area I ammonia concentrations were higher at daytime and at night. At daytime the difference reached 1,34 time, at night - 1,22 time, whereas at night area II showed a 1,05 time higher concentration than area I. An average ammonia concentration in area I reached $0,14 \mathrm{mg} / \mathrm{m}^{3}$, in area II $-0,12 \mathrm{mg} / \mathrm{m}^{3}$, and the difference was 1,14 time.

The MPC was not exceeded at any of the measuring points. Maximum recorded values of ammonia concentration were at measuring points 1,2 and 16 . These measuring points were located in the closest proximity to a fertilizer unloading unit in the AB KLASCO territory, what could result in an increase of ammonia concentration. Only some traces of ammonia concentration were detected in the samples taken from measuring points 3, 4, 6, 9, 13 and 14 during the whole day.

Ammonia concentration measured in October is presented in Fig 6.

At daytime and in the evening average concentrations reached $0,049 \mathrm{mg} / \mathrm{m}^{3}$ and $0,031 \mathrm{mg} / \mathrm{m}^{3}$, respectively, and at night they fell to $0,013 \mathrm{mg} / \mathrm{m}^{3}$.

Areas I to and II showed different ammonia concentrations in the ambient air - area I had higher concentrations, at daytime this difference was 3,01 times, in the evening $-1,91$ time and at night $-1,48$ time. An average ammonia concentration in area I reached $0,21 \mathrm{mg} / \mathrm{m}^{3}$, in area II $-0,09 \mathrm{mg} / \mathrm{m}^{3}$, and the difference was 2,29 times.

The MPC was not exceeded at any of the measuring points. The highest recorded values of ammonia concentration were at measuring points 4 and 5. Only some traces of ammonia concentration were detected in the samples taken from measuring points 9 and 10 throughout the whole day.

Fig 7 shows ammonia concentrations measured in northern Klaipèda in November.

Average ammonia concentrations within the whole day had a decreasing tendency. At daytime and in the evening average concentrations were $0,044 \mathrm{mg} / \mathrm{m}^{3}$ and $0,025 \mathrm{mg} / \mathrm{m}^{3}$, respectively, and at night they decreased to $0,018 \mathrm{mg} / \mathrm{m}^{3}$.

In area I ammonia concentrations were higher at daytime, and the difference was 2,07 times, in the evening - 1,64 time and at night $-1,05$ time. An average ammonia concentration in area I approached $0,04 \mathrm{mg} / \mathrm{m}^{3}$, in area II $-0,03 \mathrm{mg} / \mathrm{m}^{3}$ and at night $-0,02 \mathrm{mg} / \mathrm{m}^{3}$.

The MPC was not exceeded at any of the measuring points. The highest recorded values of ammonia concentration were at measuring points 5-7 during daytime measurements. They amounted to $0,32-0,36$ of the MPC. Only some traces of ammonia concentration were detected in the samples taken from measuring points 10 and 12 throughout the whole day.
Survey of ammonia concentrations measured in northern Klaipèda from June to November shows that they were higher at daytime and at night in area I (10$50 \mathrm{~m}$ from the AB KLASCO territory) than in area II (200-300 from the AB KLASCO territory). The results of measurements taken in October and November show that ammonia concentrations in area I throughout the whole-day measurements (at daytime, in the evening and at night) were higher than in area II. Differences between ammonia concentrations recorded in areas I and II, difference between the time of the day and measuring period emerged due to changing meteorological conditions and operations related to liquid fertilizer transportation and transhipment.

The above mentioned distribution of ammonia concentration in areas I and II, in fact, was predetermined by the wind force. At daytime, when the wind force was weaker, ammonia spread from liquid fertilizers being transhipped at a smaller distance, while in the evening, when the wind got stronger, ammonia is spread at a longer distance. Consequently, evening measurements showed a relatively higher ammonia concentration in area II. Night measurements showed a considerably higher ammonia concentration in area I compared to area II, which was predetermined by increased relative humidity. Relative humidity during the day increased from $4 \%$ in November to $9 \%$ in July and $12 \%$ in August.

A big difference between measuring results at daytime, in the evening and at night was also influenced by stevedoring works. No stevedoring operations that could result in an increase of ammonia concentrations were carried out in the Port in the evening or at night. In addition, relative humidity during the day did not increase significantly, and it has a major influence on the spread of gaseous emissions in the atmosphere.

Over the whole measuring period ammonia concentration was decreasing within the entire day, except in the evenings in August and September when transportation of liquid fertilizers was carried out in AB KLASCO during the measurements.

A general increase in ammonia concentrations in the ambient air was observed closer to the Curonian Lagoon, and these concentrations were decreasing as the distance from the Lagoon increased.

The MPC of ammonia concentrations was recorded in such measuring places, which are surrounded by buildings to the smallest extent and are in the closest proximity to cisterns with liquid fertilizers that were present during the measurements. Therefore, the excess of ammonia MPC was directly influenced by transportation cisterns with liquid fertilizers during the measurements. In more open locations of the Port ammonia emitted into the air during stevedoring and transportation of liquid fertilizers may spread more easily to closer areas where the concentration of this pollutant increases. The airflow down the wind is forced to flow around obstacles on its way, in this way raising emissions (it is ammonia in this case) to higher atmospheric layers. In this case pollutant spread in the atmosphere improves, and lower emission concentrations are recorded above the ground [8]. 


\subsection{Phosphorus acid}

The concentration of phosphorus acid measured at daytime, in the evening and at night in June is presented in Fig 8.

An average recorded concentration was: at daytime $-0,011 \mathrm{mg} / \mathrm{m}^{3}$, in the evening $-0,008 \mathrm{mg} / \mathrm{m}^{3}$ and at night $-0,006 \mathrm{mg} / \mathrm{m}^{3}$.

Comparison of areas I and II shows that the concentrations of phosphorus acid in area I were higher at daytime (1,49 time), in the evening (1,25 time) and at night (1,16 time). Concentrations recorded in area I at daytime were 1,45 and 2,16 times higher than those recorded in the evening and at night, respectively, and in area II 1,22 and 1,67 time, respectively.

The recorded concentrations of phosphorus acid did not exceed the MPC except those measured at daytime at measuring points 1 and 2 . These points were located not far from a fertilizer unloading unit in the AB KLASCO territory. This shows that phosphorus acid concentration increased in sections which were located closer to a fertilizer unloading unit.

Phosphorus acid concentration measured in July is presented in Fig 9.

The measurements of phosphorus acid concentration in the ambient air show that it was decreasing in the course of a day. Average concentrations were: at daytime $-0,011 \mathrm{mg} / \mathrm{m}^{3}$, in the evening $-0,008 \mathrm{mg} / \mathrm{m}^{3}$ and at night $-0,007 \mathrm{mg} / \mathrm{m}^{3}$.

Comparison of areas I and II shows that the concentrations of phosphorus acid in area I were higher at daytime (2,48 times), in the evening (2,17 times) and at night (2,30 times). Concentrations recorded in area I at daytime were 1,29 time higher than those recorded in the evening and 1,56 time bigger, when compared to those measured at night, and in area II - 1,13 and 1,45 time, respectively.

The recorded concentrations of phosphorus acid did not exceed the MPC except those measured in the evening and at night at measuring point 1 , at daytime and in the evening at measuring point 2 and at daytime at measuring point 3 . These points were located not far from a fertilizer unloading unit in the AB KLASCO territory. The highest excess was recorded during evening measurements at point 2 (1,17 time).

The concentration of phosphorus acid measured in August is presented in Fig 10.

An average concentration of phosphorus acid was: at daytime $-0,010 \mathrm{mg} / \mathrm{m}^{3}$, in the evening and at night $0,007 \mathrm{mg} / \mathrm{m}^{3}$.

Comparison of areas I and II shows that the concentrations of phosphorus acid in area I were higher at daytime, in the evening and at night $1,11,1,23$, and 1,51 time, respectively. Concentrations recorded in area I at daytime were 1,39 and 1,38 time higher than those recorded in the evening and at night, respectively. In area II - 1,53 and 1,88 time, respectively.

The recorded concentration of phosphorus acid did not exceed the MPC at any of the measuring points. The highest concentration was recorded at measuring points 1 and $2\left(0,012 \mathrm{mg} / \mathrm{m}^{3}\right)$ and measuring points 3 and $14\left(0,009 \mathrm{mg} / \mathrm{m}^{3}\right)$.

The distribution of phosphorus acid was of the same character at daytime, in the evening and at night. The highest concentrations were recorded near Śvyturio Street, i e in the closest proximity to fertilizer stowage terminal, and the lowest ones - at the biggest distance from Švyturio Street.

The concentration of phosphorus acid measured in September is presented in Fig 11.

The measurements of phosphorus acid concentration in the ambient air show that it is decreasing in the course of a day. An average concentration amounted to: at daytime $-0,0098 \mathrm{mg} / \mathrm{m}^{3}$, in the evening $-0,0093 \mathrm{mg} / \mathrm{m}^{3}$ and at night $-0,0079 \mathrm{mg} / \mathrm{m}^{3}$.

Comparison of areas I and II shows that the concentrations of phosphorus acid in area I were higher at daytime, in the evening and at night 1,42 time, 1,46 and 1,30 time, respectively. Concentrations recorded in area $\mathrm{I}$ at daytime were 1,04 and 1,28 time higher than those recorded in the evening and at night, respectively. In area II - 1,07 time in the evening and at night.

The recorded concentration of phosphorus acid did not exceed the MPC at any of the measuring points.

The concentration of phosphorus acid measured in October is presented in Fig 12.

Average recorded concentrations of phosphorus acid were as follows: at daytime $-0,0108 \mathrm{mg} / \mathrm{m}^{3}$, in the evening $-0,0080 \mathrm{mg} / \mathrm{m}^{3}$ and at night $-0,0075 \mathrm{mg} / \mathrm{m}^{3}$.

Phosphorus acid concentrations in area $\mathrm{I}$, when compared to area II, were higher at daytime, in the evening and at night 1,51, 1,29 and 1,16 time, respectively. The concentrations recorded in area I at daytime were higher than those recorded in the evening and at night 1,43 and 1,58 time, respectively. In area II they were higher 1,22 and 1,21 time in the evening and at night, respectively.

The recorded concentration of phosphorus acid did not exceed the MPC in any of the measuring points. Values the closest to the MPC were recorded during daytime measurements at measuring points 1-4. At these points phosphorus acid concentration was from $0,0158 \mathrm{mg} / \mathrm{m}^{3}$ to $0,0183 \mathrm{mg} / \mathrm{m}^{3}$. This accounts for 0,79 and 0,92 of the MPC, respectively.

The concentration of phosphorus acid measured in November is presented in Fig 13.

The concentration of phosphorus acid in the ambient air was decreasing in the course of a day. Average recorded concentrations were: at daytime $-0,0051 \mathrm{mg} / \mathrm{m}^{3}$, in the evening - $0,0033 \mathrm{mg} / \mathrm{m}^{3}$ and at night $0,0027 \mathrm{mg} / \mathrm{m}^{3}$.

Phosphorus acid concentrations in area I, when compared to area II, were higher at daytime, in the evening and at night 1,54, 1,80 and 1,63 time, respectively. The concentrations recorded in area I at daytime were higher than those recorded in the evening and at night 1,45 and 1,80 time, respectively. In area II they were higher 1,69 and 1,90 time in the evening and at night, respectively. 

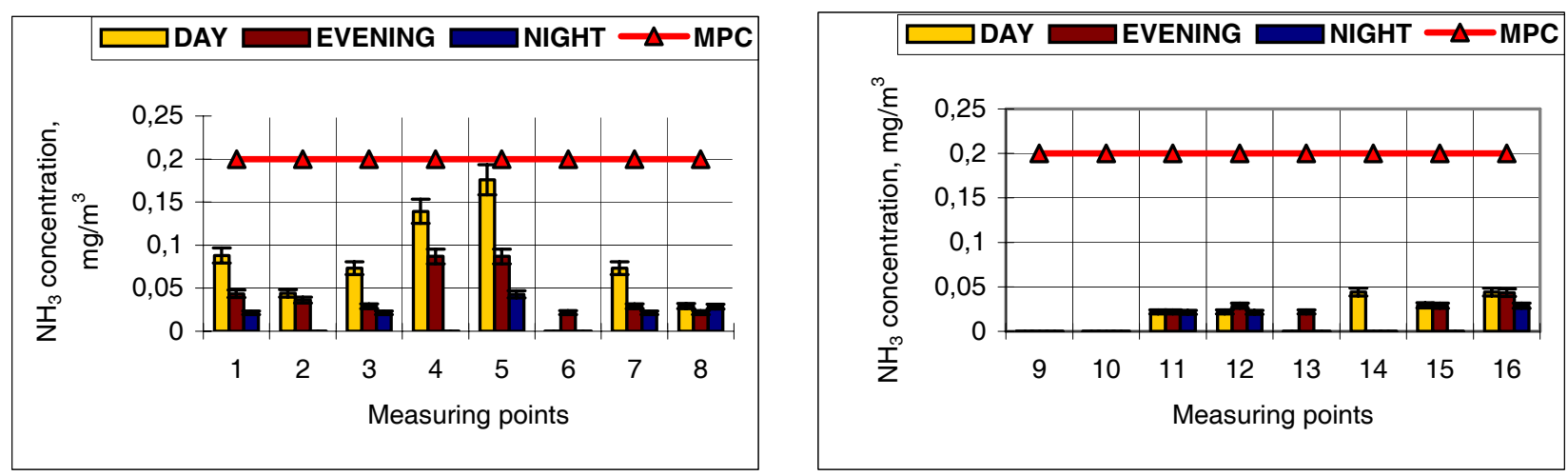

Fig 6. Ammonia concentration 10-50 m and 200-300 m from AB KLASCO territory in October
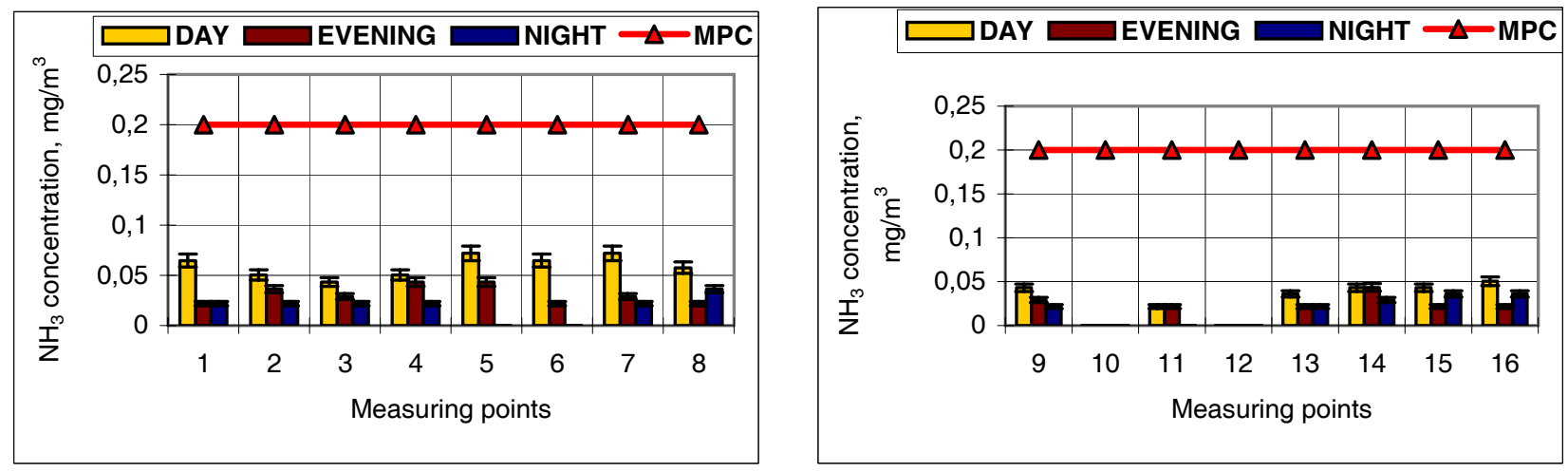

Fig 7. Ammonia concentration 10-50 m and 200-300 m from AB KLASCO territory in November
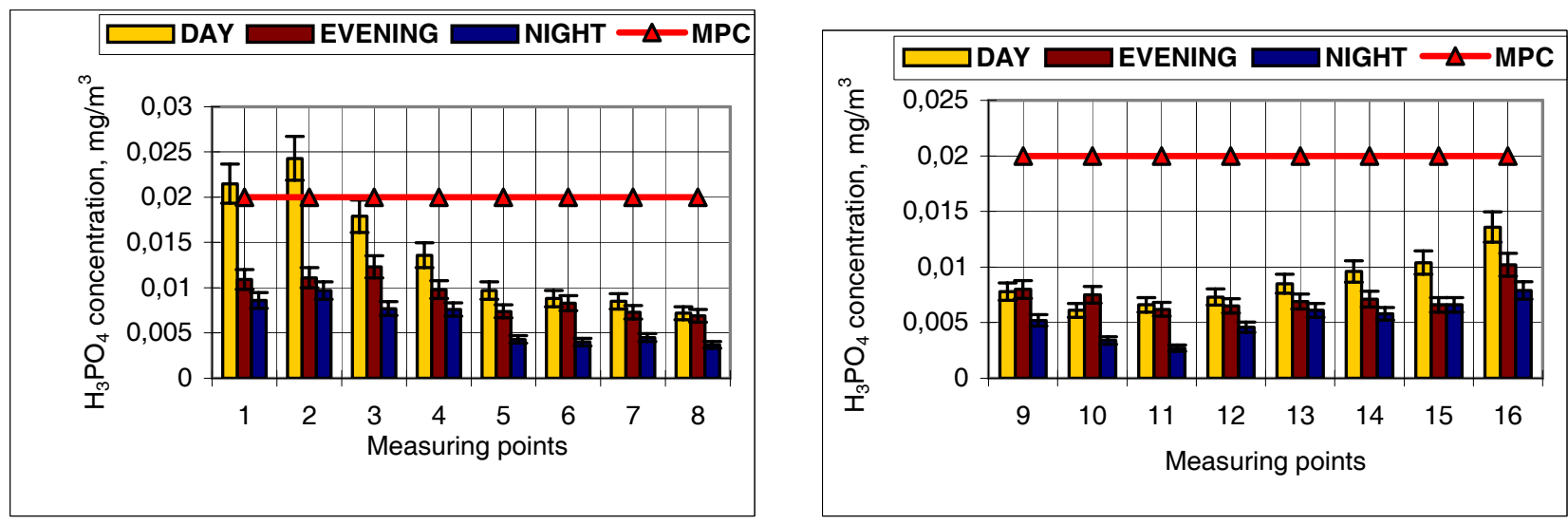

Fig 8. Phosphorus acid concentration 10-50 m and 200-300 m from AB KLASCO territory in June
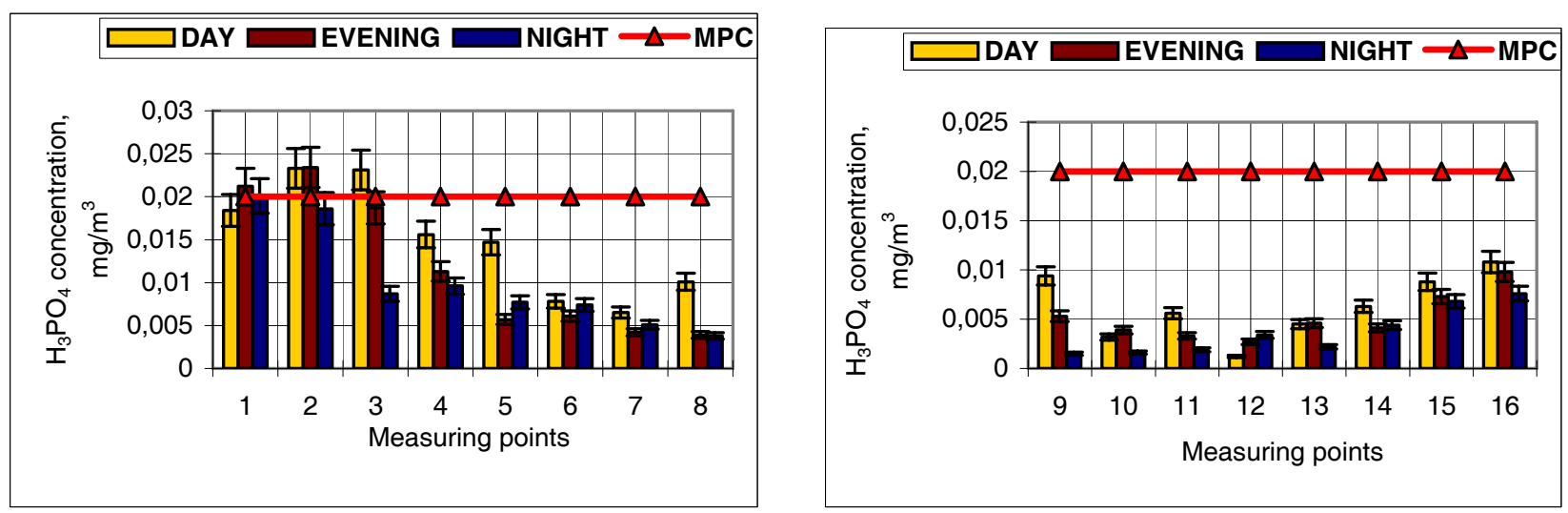

Fig 9. Phosphorus acid concentration 10-50 m and 200-300 m from AB KLASCO territory in July 

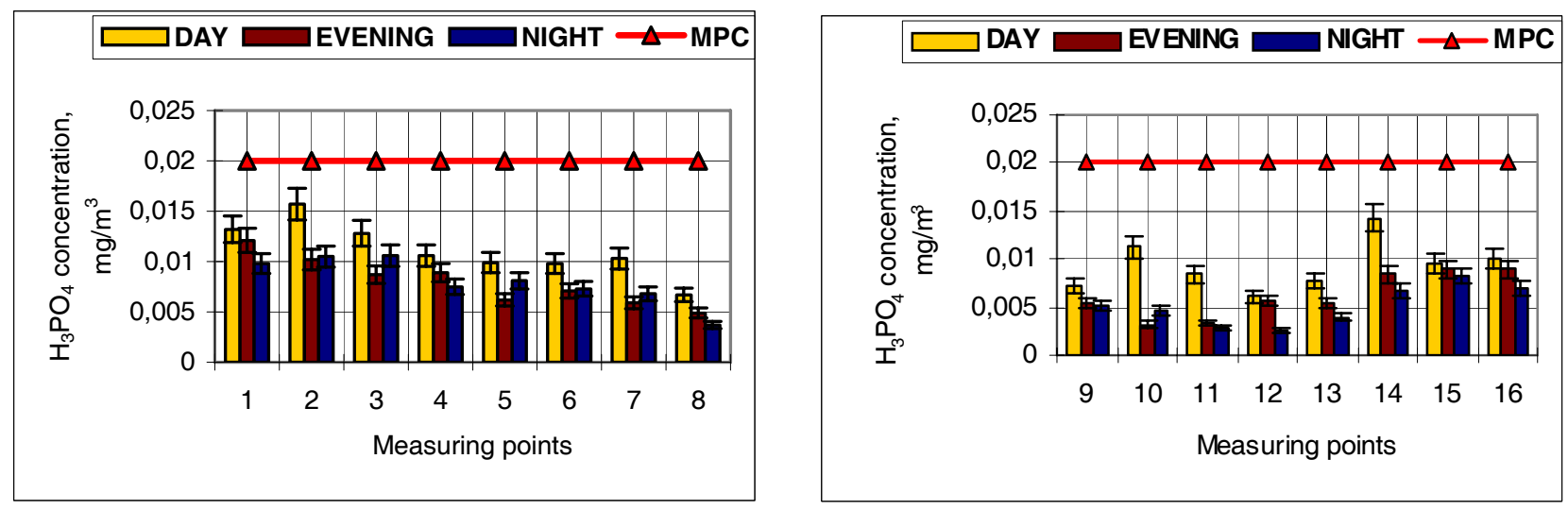

Fig 10. Phosphorus acid concentration 10-50 m and 200-300 m from AB KLASCO territory in August
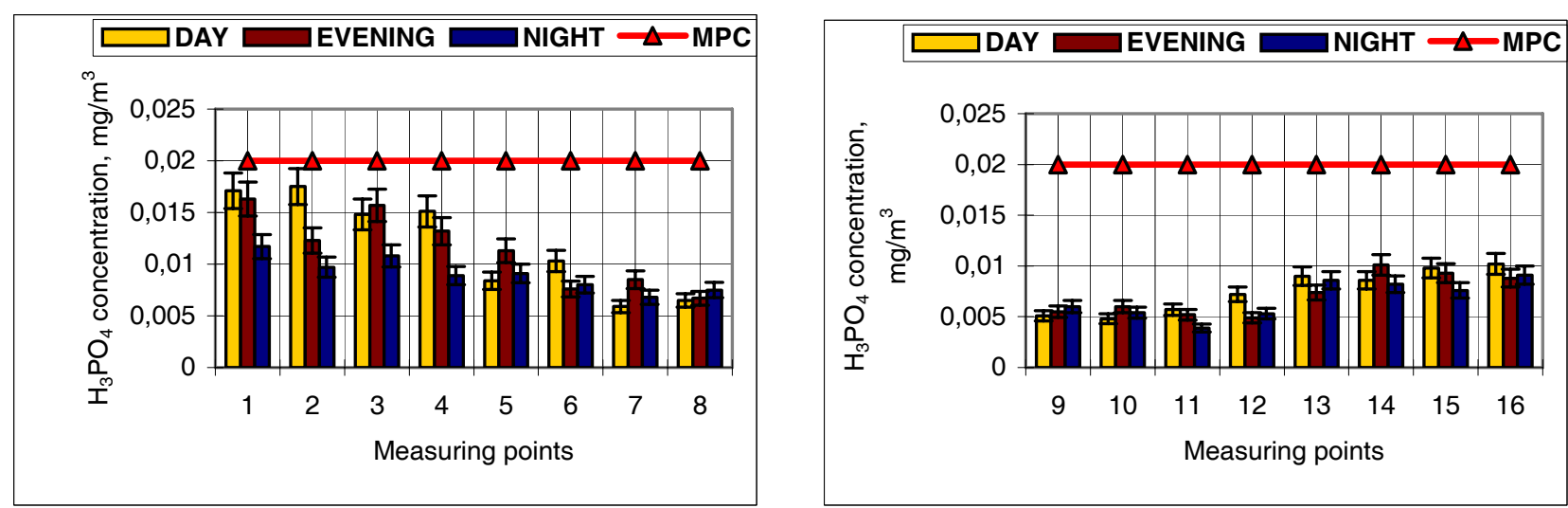

Fig 11. Phosphorus acid concentration 10-50 m and 200-300 m from AB KLASCO territory in September
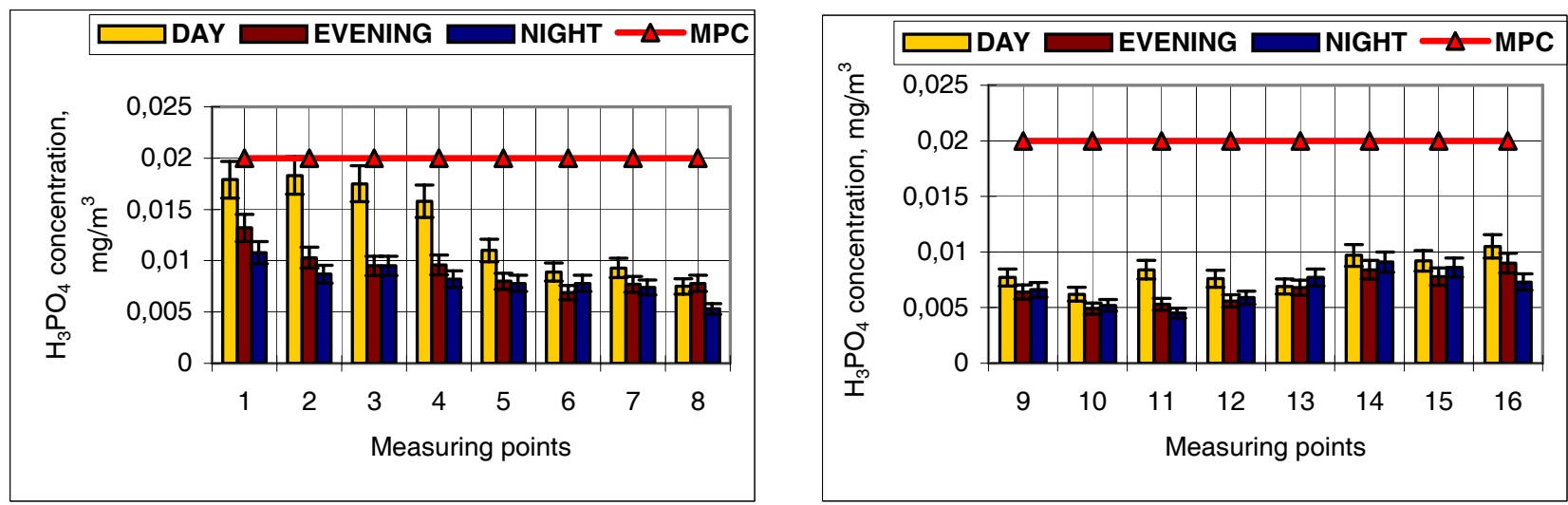

Fig 12. Phosphorus acid concentration $10-50 \mathrm{~m}$ and 200-300 m from AB KLASCO territory in October
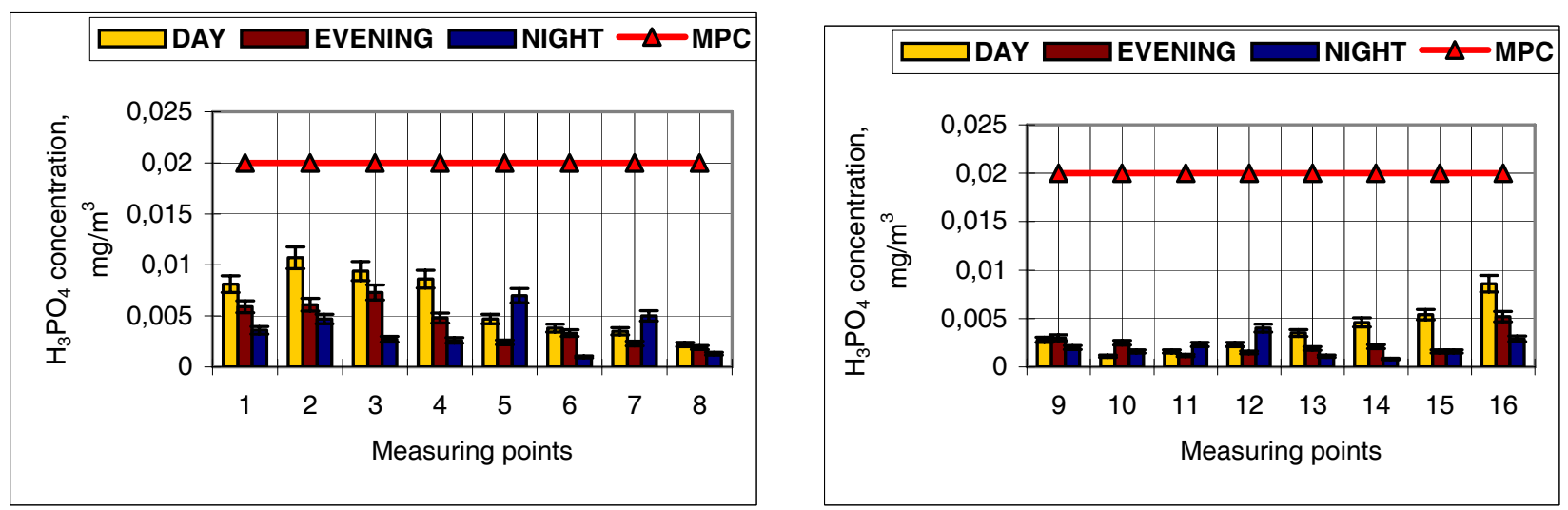

Fig 13. Phosphorus acid concentration 10-50 m and 200-300 m from AB KLASCO territory in November 
The recorded concentration of phosphorus acid did not exceed the MPC in any of the measuring points. Values the closest to the MPC were recorded during daytime measurements at measuring points $1-4$ and 16 . Since a fertilizer stowage unit of AB KLASCO was located close to these points, this could have an influence on an increase in concentration.

The measurements of phosphorus acid concentrations in the ambient air in the period from June to November show that the highest concentrations of this emission were at measuring points $1-3$ and 16 . These measuring points were located in the closest proximity to powdery fertilizer terminal in the AB KLASCO territory.

Daytime, evening and night measurements show different concentrations of phosphorus acid in area I (10$50 \mathrm{~m}$ from the AB KLASCO territory) and area II (200$300 \mathrm{~m}$ from the AB KLASCO territory). In area I the concentration of phosphorus acid at daytime was higher than in area II 1,11 time (in August) and 2,48 times (in July): in the evening -1,23 time (in August), 2,17 times (in July); at night - 1,16 time (in October and June) and 2,30 times (in July).

Even though no stevedoring operations of fertilizers containing phosphorus were carried out during the measurements, an increase in pollutant concentration may be related with particles lifted by the wind from previous stevedoring operations. Taking into consideration the fact that particles containing phosphorus compounds were not transmitted from stevedoring operations, the largest accumulations had thereof precipitated on the ground surface. Only when the wind arose and lifted the particles into the air, the concentration of phosphorus acid was recorded in the ambient air. For this reason, maximum pollutant concentration values were recorded in the closest proximity of a fertilizer stevedoring unit, and when a distance from it increased phosphorus acid concentrations became lower.

The measurement results of phosphorus acid concentration show that the concentration was decreasing in the course of a day. The reduction of concentration was influenced not only by the wind but also by relative air humidity. As it has been mentioned, relative air humidity during the day increased from $4 \%$ in November to $9 \%$ in July and $12 \%$ in August. As relative humidity increases, the amount of particles raised from the ground decreases in the ambient air and at the same time phosphorus concentration does.

The influence of relative air humidity was noticed in the course of all the measurements. The concentration of phosphorus acid in particular decreased in October and November when relative humidity, compared to the summertime, on average, increased by around $8-10 \%$.

Maximum MPC excess of phosphorus acid was recorded at daytime in June (22\%), at daytime and in the evening in July $(17 \%)$ near measuring place 2 (by the crossroad of Švyturio and Pušyno Streets). It can be mainly influenced by fertilizers containing phosphorus that had been previously transhipped at fertilizer stowage terminal, what resulted in an increase of phosphoric compounds in the surrounding territory.

\section{Conclusions}

The air pollution with ammonia and phosphorus acid in northern Klaipedda was analysed.

1. Ammonia MPC excess was recorded during daytime, evening and night measurements in June. The MPC excess was also detected during daytime and evening measurements in July and during evening measurements in August. Maximum MPC excess was recorded at daytime and in the evening (1,1 time), and at night (2,2 times) in June. In September, October and November ammonia concentrations in the ambient air did not exceed the MPC.

2. In comparison of summer period to autumn months an average ammonia concentration decreased from $0,11 \mathrm{mg} / \mathrm{m}^{3}$ to $0,04 \mathrm{mg} / \mathrm{m}^{3}$ at daytime, and to $0,02 \mathrm{~g} / \mathrm{m}^{3}$ in the evening. Ammonia concentrations at night decreased from $0,15 \mathrm{mg} / \mathrm{m}^{3}$ in summertime to $0,017 \mathrm{mg} / \mathrm{m}^{3}$ in autumn.

3. From June to September ammonia concentration in area I of northern Klaipeda was higher than in area II at daytime and at night. The results of measurements made in October and November show that ammonia concentration throughout the day (at daytime, in the evening and at night) was higher in area I compared to area II.

4. In the course of a day and measuring period ammonia concentration decreased as the wind speed fell and relative air humidity increased.

5. It can be stated that ammonia concentrations and distribution thereof were mainly influenced by meteorological conditions during measuring operations - the wind force and relative air humidity - and transportation of liquid fertilizers.

6. In November compared to July, phosphorus acid concentration at daytime was lower 2,1 times, in the evening $-2,6$ times, at night $-2,5$ times.

7. In summertime compared to autumn, an average concentration of phosphorus acid decreased from $0,11 \mathrm{mg} / \mathrm{m}^{3}$ to $0,009 \mathrm{mg} / \mathrm{m}^{3}$ at daytime, from $0,008 \mathrm{mg} / \mathrm{m}^{3}$ to $0,007 \mathrm{mg} / \mathrm{m}^{3}$ in the evening. At night ammonia concentrations decreased from $0,007 \mathrm{mg} / \mathrm{m}^{3}$ in summertime to $0,006 \mathrm{mg} / \mathrm{m}^{3}$ in autumn.

8. In area I compared to area II, phosphorus acid concentration at daytime was higher 1,11 time (in August) and 2,48 times (in July); at night - 1,23 time (in August) and 2,17 times (in July); at night - 1,16 time (in October and June) and 2,30 times (in July).

9. Phosphorus acid concentrations could be for the most part influenced by fertilizers containing phosphorus that had been previously transhipped at fertilizer stowage terminal, what resulted in an increase of phosphoric compounds in the surrounding territory.

10. In addition, phosphorus acid concentration was influenced by relative air humidity. As relative air humidity increased, the concentration of phosphorus acid decreased. 


\section{References}

1. Environment condition 2002 (Aplinkos būklè 2002). Ministry of Environment of the Republic of Lithuania. Vilnius, 2003, p. 14-20 (in Lithuanian).

2. Baltrènas, P. Environmental pollution in Lithuania and its decrease strategy. In: Reports from Environmental Protection Section of International Conference "Urban Engineering and Environment” (Tarptautinès konferencijos „Miestu inžinerija ir aplinka“" Atmosferos apsaugos sekcijos medžiaga). Vilnius: Technika, 1994, p. 3-7 (in Lithuanian).

3. Baltrènas, P.; Taločkaite, E.; Vasarevičius, S. Atmosphere pollution at Radviliškis railway junction and its reduction. Environmental Engineering (Aplinkos inžinerija), Vol VII, No 2, 1999, p. 63-70. ISSN 1392-1622 (in Lithuanian).
4. Baltrènas, P.; Vasarevičius, S. Evaluation of air pollution at Vilnius railway junction. Environmental Engineering (Aplinkos inžinerija), Vol VI, No 3, 1998, p. 88-93. ISSN 1392-1622 (in Lithuanian).

5. Vekteris, V.; Kasparaitis, A. ir kt. Measuring theory and practice (Matavimu teorija ir praktika). Vilnius: Žiburys, 2000. 380 p. (in Lithuanian).

6. Kavaliauskienė, G.; Sakalauskas, S. Metrology introduction (Metrologijos įvadas). Vilnius: Mokslas, 1993. 152 p. (in Lithuanian).

7. Lithuanian Hygiene Standard HN 35-2002. "Limit concentration values of air pollutants in living environment".

8. Baltrènas, P.; Špakauskas, V.; Vaitiekūnas, P. Digital simulation of heavy calibrated aerosol dispersion. Environmental Engineering (Aplinkos inžinerija), No 2(8), 1997, p. 4-12. ISSN 1392-1622 (in Lithuanian).

\section{SKYSTŲJŲ IR BIRIŲJŲ TRĄŠŲ KROVOS DARBŲ KLAIPE்DOS VALSTYBINIAME JŪRŲ UOSTE ITAKA APLINKOS ORO KOKYBEI}

\section{P. Baltrėnas, M. Kvasauskas, K.-D. Frőhner}

Santrauka

Klaipėdos valstybiniame jūrų uoste vykdoma ūkinė veikla neigiamai veikia aplinkos oro kokybę. Klaipėdos šiaurinės dalies atmosferos užterštumui dẻl ūkinès veiklos uoste ìvertinti birželio - lapkričio ménesiais buvo atliekami tyrimai. Straipsnyje apžvelgiamas skystujų ir biriujuc trą̌̌̌ krovos ir transportavimo darbų poveikis aplinkos orui. Atlikus amoniako ir fosforo rūgšties koncentracijų ore matavimus nustatyta, kad amoniako koncentracijoms ir jų pasiskirstymui didžiausią ịtaką turèjo meteorologinès sąlygos matavimų metu: vèjo stiprumas ir santykinè oro drègmè bei skystuju trąšu transportavimas. Maksimaliai amoniako DLK viršytos birželį. Dieną ir vakare - 1,1 karto, nakti - 2,2 karto. Rugsėjo, spalio ir lapkričio mėnesiais amoniako koncentracijos aplinkos ore DLK neviršijo. Fosforo rūgšties koncentracijos viršytos 1,2 karto birželi dienomis bei liepą dienomis bei vakarais arčiausiai biriujų trąšu perkrovimo terminalo. Fosforo rūgšties koncentracijai didžiausią itaką galèjo turèti anksčiau vykę trąšu perkrovimo terminale darbai bei santykinè drègmė. Fosforo turinčių trą̌šu perkrovimas lèmé fosforo junginių kiekio padidèjimą aplinkinèje teritorijoje.

Prasminiai žodžiai: oro tarša, amoniako koncentracija, fosforo rūgšties koncentracija, meteorologinès sąlygos.

\section{ВЛИЯНИЕ РАБОТ ПО РАЗГРУЗКЕ ЖИДКИХ И ПОРОШКООБРАЗНЫХ УДОБРЕНИЙ, ПРОИЗВОДИМЫХ В КЛАЙПЕДСКОМ ГОСУДАРСТВЕННОМ МОРСКОМ ПОРТУ, НА КАЧЕСТВО ВОЗДУХА ОКРУЖАЮЩЕЙ СРЕДЫ}

\section{П. Балтренас, М. Квасаускас, К.-Д. Френер}

Р е $з$ ю м

Осуществляемая в Клайпедском государственном морском порту хозяйственная деятельность отрицательно сказывается на качестве воздуха окружающей среды. Для оценки влияния хозяйственной деятельности, производимой в Клайпедском морском порту, на качество воздуха северной части города с июня по ноябрь проводились исследования. Изучалось влияние на качество воздуха работ по разгрузке жидких и порошкообразных удобрений. Измерение концентраций аммиака и фосфорной кислоты в воздухе показало, что наибольшее воздействие на распределение концентраций аммиака оказывали метеорологические условия во время измерений: сила ветра и относительная влажность воздуха, а также транспортировка жидких удобрений. Наибольшее превышение максимально допустимой концентрации (МДК) аммиака в 1,1 раза в дневное время и в 2,2 раза ночью зарегистрировано в июне. В сентябре, октябре и ноябре концентрации аммиака в окружающем воздухе не превышали МДК. Избыток фосфорной кислоты в окружающем воздухе был зафиксирован в июне (в 1,2 раза в дневное время) и июле (в дневное время и вечером) в непосредственной близости от терминала по разгрузке жидких удобрений. На концентрацию фосфорной кислоты наибольшее влияние могли оказать ранее производившиеся в терминале работы по разгрузке удобрений, содержащих фосфор, а также относительная влажность воздуха.

Ключевые слова: загрязнение воздуха, концентрация аммиака, концентрация фосфорной кислоты, метеорология.

Pranas BALTRE்NAS. Dr Habil, Prof and head of Dept of Environmental Protection, Vilnius Gediminas Technical University (VGTU).

Doctor Habil of Science (air pollution), Leningrad Civil Engineering Institute (Russia), 1989. Doctor of Science (air pollution) Ivanov Textile Institute (Russia), 1975. Employment: Professor (1990), Associate Professor (1985), senior lecturer (1975), Vilnius Civil Engineering Institute (VISI, now VGTU). Publications: author of 13 monographs, 24 study-guides, over 320 research papers and 67 inventions. Honorary awards and membership: prize-winner of the Republic of Lithuania 
(1994), a corresponding Member of the Ukrainian Academy of Technological Cybernetics, a full Member of International Academy of Ecology and Life Protection. Probation in Germany and Finland. Research interests: air pollution, pollutant properties, pollution control equipment and methods.

Mindaugas KVASAUSKAS. Master, doctoral student, Dept of Environmental Protection, Vilnius Gediminas Technical University (VGTU).

Master of Science (environmental engineering), VGTU, 2005. Publications: author of 5 research papers. Research interests: environmental protection, pollution control.

Klaus-Dieter FRŐHNER. Dr, Hamburg-Harburg Technical University, Institute of Ergonomics.

Doctorate to the qualified engineer in the University of Technology of Berlin, 1973. Main certificate in the technological university of Berlin, 1969. Leader of the study group Production Planning and Production Control of the German Society for Operations Research, 1974-1979. Leader of Lübeck Engineer Asociation, 1979-1982. Foundation member on suggestion of the science council of the Federal Ministry of research and technology and Federal Ministry of work of the Federal Republic of Germany financed committee to the investigation of the social and political change in the new federal states; coordination of the industrial safety-related research of the committee. Publications: author of 14 monographs, over 150 research papers. 